\title{
Environmental Consequences of Coal Mine Elimination
}

\author{
Tatyana Tyuleneva \\ Institute of economics and management \\ T. F. Gorbachev Kuzbass State Technical University \\ Kemerovo, Russian Federation \\ krukta@mail.ru
}

\begin{abstract}
Mines have an impact on all components of the environment during and after coal mining. Process of restructuring coal industry and elimination of unprofitable mines changes anthropogenic impact on the environment. Structural and technological change in the geological massif is terminated, but other types of negative impact on the environment continue become more active. Elimination of coal mines is accompanied by the emergence of new phenomena and processes that were not in the period of operation of enterprises and that have a negative environmental impact. The degree of impact of the mine on the environment depends on many factors - geological conditions, hydrogeological factors, development and quality of land allocated for mine workings. As a result of the combined effect of negative factors during mine elimination, sustainable increase in the area of territories with active development of flooding communal and industrial facilities, agricultural lands, communication facilities, transport highways are appeared. As a consequence processes of pollution of surface water and groundwater are activated, that combined with ground surface depression, accumulation of potential energy in flooded mine workings with the formation of hydro-geo-mechanical stresses and decrease of resistance of rock masses. Geochemical pollution of industrialurban and agricultural landscapes is observed almost everywhere. The paper lists types of environmental pollution that occurred after elimination of coal mines. Possible ways of solving environmental problems of mine elimination are considered.
\end{abstract}

Keywords - mine elimination, environmental consequence, technogenic influence, coal industry

\section{INTRODUCTION}

Mines have a negative impact on the environment both during and after coal mining. The degree of change of the geological environment is different at all stages of coal mining. It will be maximum during the construction of main mine workings and at the beginning of mining operations, and it will be minimum at the stage of mine elimination. The degree of mine's impact on the natural environment depends on many factors, such as mining and geological conditions (coal reserves, coal bedding and angle of inclination, rock strength, system of seam development and their depth, gas content of rocks), hydrogeological factors (condition and dynamics of groundwater, water saturation of seam), construction and quality of land allocated for mine exploitation. At the first and second stages (exploitation beginning of a mine and its achievement of design capacity), coal mining affects mainly the lithosphere, atmosphere, at the third stage of operation (the main period of an activity) mine affects the lithosphere and hydrosphere, at the last stage (mine elimination) - all from components of the ecosystem, although with less intensity. Unfortunately, little attention is paid to the final stage of the mine life in scientific research.

Kuzbass coal began to be mined before the Great Patriotic War. In 193018 mines were put into operation in Kuzbass, in next two years 32 ones were done, and in 1934194014 ones were constructed here. In 1990 the region had 74 mines, each of them was with a standard service life of 50 years. This period was considered as quite significant, and few people thought about what to do after its end. Design developments for the stage of mine elimination were not carried out. In addition environmental problems arising from the mine elimination have been issued in last 10 years only. By this time the coal production in Kuzbass reached the highest number (more than 160 million tons per year), with a third of the coal extracted in open-cut mining. By the end of the 80-ies. coal miners of the country faced the task of ensuring high efficiency, and it was necessary to get answers to many questions for this: how much coal the country needs; what method of coal mining should be a priority; whether to build new mines or to reconstruct old ones; how to develop new deposits; whether to build the new city of Uskat in Kuzbass. In the 90-ies, during a period of so-called restructuring of coal industry, the mine elimination was given greater stage. At that time 43 mines were closed all over Russia, without proper thorough social and environmental justification. Those measures led to the aggravation of socio-economic situation in mining regions of the country, mass unemployment among miners began. The closure of a number of mines in recent years is caused by objective circumstances. Thus, from 36 mines in Kuzbass region in recent years has been eliminated 21 ones with service life of 50 years or more - basically they were mines with worked-out reserves of coal. 10 mines with service life from 40 to 50 years were also closed, construction of new mines was interrupted. All this has caused serious environmental problems. Hydrogeological situation became more complicated flooding of mines, penetration of their gases into structures and buildings [1]

Lithospheric and hydrospheric disturbances are varied in different regions of Kuzbass. For example, Prokopyevsk and Kiselevsk areas are characterized by disturbances in a form of dips in the surface, Belovo and Kemerovo ones are characterized by flooding, gas emission observed in mines of Belovo and Leninsk-Kuznetskiy with high gas saturation and thus a fire hazard seams. All these issues had to be carefully analyzed and worked out at the stage of designing the mine. 
The peculiarity of Kuzbass mines is the presence of a large number of pits and shafts, which, according to the existing safety rules, at the closure of the enterprise must be eliminated. The area of disturbed lands in the Kemerovo region is 10 times more than the average in Russia. Analysis of the current situation in the coal industry due to the mass closure of unprofitable enterprises indicates the ambiguity of the impact of this process on the environment both in the zone of direct impact of each of these enterprises, and coal basins and regions as a whole [2].

\section{MATERIALS AND METHODS}

The negative impact of mass mine elimination process affects all elements of the natural environment: its water, air components, landscape and biosphere. A result of mine elimination was a decrease of mine water discharges, however recovery of groundwater levels as mines are flooded is accompanied by negative consequences, such as flooding of cities and towns territories, farmlands, engineering structures, significant change in the initial chemical composition and physical properties of drainage waters. Drained into the surface basins water bodies of flooded mines have a high content of hard metals and trace elements exceeding MAC values [3].

Flooded mines have a hydraulic connection with the operating ones, which leads to significant flows of water pumping in operating mines. This fact causes the need for large additional costs to increase a drainage in operating mines. Flooding of worked-out areas of mine elimination leads to the displacement of polluted mine air. Enriched with methane and radioactive elements deoxidized air accumulates in closed spaces and is a danger to human life, which has repeatedly led to tragic consequences.

Increased concentrations of methane and carbon dioxide and reduced oxygen content ("dead" air) were recorded during environmental monitoring at mine closure. Results of measurements of methane, carbon dioxide and oxygen concentrations showed an increased content of methane and carbon dioxide in basements of private houses. Decrease in oxygen content was recorded in basements of buildings. After mines eliminated on a part of worked-out area there are subsidence of the earth's surface with appearance of relief depressions, soil degradation, violations integrity of buildings and structures, formation of wetlands in the depressions of the relief.

Flooding large amounts of exhausted mines is accompanied by the change of stress condition of rock massif, intensification of the seismic manifestations of rock pressure. Seismic observations carried out in various coal regions of the country, note the activation of seismic events, periodically register technogenic earthquakes up to 3-4 points on the Richter scale. The processes of settling the earth's surface with the formation of bends, dips, craters, cracks continue, and in some cases intensify, resulting in flooding of the exhausted areas, where industrial buildings and structures, villages, valuable agricultural lands and forests are located [4].

Closure of mines leads to a reduction in emissions of pollutants into the atmosphere as a result of decreasing of operating industrial boilers, loading and transport processes in mines and concentrating mills, systems of removal of mine air from an exhausted area during the ventilation of mines, however activates other sources of air pollution. All these things lead to a decrease in technogenic load and has a beneficial effect on the state of the natural environment. On the other hand, mine elimination is often accompanied by very dangerous environmental consequences [5]. Main factors of negative impact on the environment of eliminated mines include the termination of production activity, a result of which is very complex production infrastructure that does not correspond with natural landscape; flooding of exhausted mines, accompanied by a deep negative impact on groundwater and surface water; removed storage of solid and liquid waste products, which include flat and conical rock heaps, open coal storages, mud collectors, water heaps, setting basins, and various technogenic basins, occupying extensive grounds, which are intense sources of pollution of underground and surface waters, atmospheric air and does not serve as a decoration of the natural landscape; the industrial site, violated, polluted and degraded land which cannot be used in its current form and are subject to recultivation).

These processes include continuous emissions with ventilation flow of pollutants (thin disperse coal-rock dust, methane, carbon dioxide, hydrogen sulfide and other harmful gases); pumping to the surface and discharge mining and pit waters with increased mineralization, high iron content and acidic, polluted by suspended solids, oil products, phenols, bacterial impurities into natural water bodies; input on the surface are prone to spontaneous combustion of rock mass and placing it in the conical and flat natural dumps; withdrawal from land use and violation of new plots of land often agricultural and forestry purposes; input on the surface of coal and subsequent operations for its unloading, loading, transportation, storage in opened coal warehouses, enrichment, processing and burning; a number of auxiliary processes and productions, without which it is impossible to conduct mining and preparatory work in mines and pits.

The depth and degree of environmental hazard arising under the influence of these factors are due to a combination of environmental and mining conditions, which have specific features, and differ in coal basins, deposits and enterprises [6]. For this reason, the necessary set of measures to prevent, localize and eliminate negative environmental consequences should be developed before the start of technical works on mine elimination at the stage of pre-design work and design.

In the vast majority of cases, mine elimination is carried out by flooding. The termination of pumping from eliminated mines leads to a significant change in the hydrodynamic regime of groundwater, and above all, to the restoration of their original level, which occurred before the start of mining. Changes, as a rule, in the direction of decrease, the chemical composition of mine waters, which is expressed in increasing the degree of mineralization of water, iron content, a number of trace elements, including those with toxic properties. Nearby underground sources of drinking water supply can be contaminated and damaged. Often flooding of mines is accompanied by outflow of mine waters on a surface. The most difficult problems arise in the case of mines` group elimination that has a close hydraulic connection with each other. The presence of such connection usually leads to a high degree of pollution of mine waters coming from deep horizons, and high costs of 
mine waters. The most dangerous ingredients are mineral salts, high acidity and high iron content. These categories of mine waters pose the greatest danger to surface waters. Large damage to waters is also caused by stocks of rock dumps and industrial sites, which are characterized, as a rule, by even higher concentrations of pollutants.

A dangerous phenomenon associated with the flooding of mines, is the formation of explosive concentrations of methane and other harmful gases in the mine workings in the performance of technical work, and on the surface of mines in the process of flooding. As practice shows, gas safety at performance of technical works on mine elimination can be provided at the expense of the reliable forecast of allocation and migration of methane, reliable ventilation of mine, a permanent control of a condition of the air environment in places of a possible accumulation of methane. For these purposes, in advance, should be developed the scheme of ventilation of mine with regard to their maturity. After complete filling of the shafts, gas is discharged from the worked-out space through degassing pipes brought to the surface through the overlaps of the shafts. If a dangerous accumulation of methane is detected, emergency measures are taken to eliminate it.

Dangerous emissions of methane and other harmful gases to the earth's surface during flooding of mines are caused by increase of water level in the worked-out space and its displacement on higher horizons, and then and penetration into basements of buildings. In order to prevent the gassing buildings, an important role is played by forecasting and systematic control of gas accumulations, timely development and implementation of operational measures for the degassing of facilities. Experience shows that after a completed flooding of mines, as a rule, after 3-6 months, the flow of methane to the surface is significantly reduced, and then completely stopped.

For mine elimination should take into account the effect on the atmosphere of the boiler and coal bin and dumps. Today, the closed and collapsing Kuzbass mines continue to pollute the environment. For example, the area around the mines Krasnogorskaya, Taibinskaya, Vakhrusheva represent more than 10 quarter kilometers of surface with destroyed buildings, structures and failures [7].

As a result of the combined effect of negative factors during mine elimination, there is a sustainable increase in the area of territories with the active development of flooding of housing and communal and industrial facilities, agricultural lands, communication facilities, transport highways. As a consequence processes of pollution of surface water and groundwater, depression of the ground surface, the accumulation of potential energy in the flooded mine workings with the formation of hydro-geo-mechanical stresses and decrease of the resistance of rock masses developed. At the same time, the structure of the flows of explosive gases is changing, which can complicate the gasgeochemical conditions of operating mines and adjacent industrial and urban agglomerations. Almost everywhere there is geochemical pollution of landscapes of industrialurban and agricultural areas, expressed in the growth of concentrations of hard metals, petroleum products in soils, snow cover, bottom sediments [8]. There has been a sustainable increase of salinity and pollution by nitrates, hard metals groundwater and surface water. Radiochemical pollution of soils and groundwater with uranium-radium- containing minerals is appearing in some areas, mainly in the zones of influence of mud collectors.

The negative consequences of the elimination of unprofitable mines are integral and are reflected not only in the environmental, but also in the social sphere. The impact on the social sphere is expressed primarily in the deterioration of living conditions of the population in the zone of influence of eliminated mines, and is associated with pollution of atmospheric air, waters, reduction of protective functions of forest plantations.

\section{RESULTS AND DISCUSSION}

With the termination of mining, the elimination and flooding of mines and pits, the environmental danger takes place, previously caused environmental damage does not disappear completely, there are and may be in the future new sources of danger to the environment in the zone of their influence. Therefore, in the projects of mine elimination should be provided and further implemented a system environmental monitoring and a full range of environmental measures, taking into account all sources of pollution and factors of negative impact on the environment. Mine elimination is often accompanied by very dangerous environmental consequences.

The main factors of negative impact of the eliminated mines and pits on the environment and technical solutions to prevent it are shown in table 1 [9].

The depth and degree of environmental hazard arising under the influence of these factors are due to a combination of environmental and mining conditions, which have specific features, and differ in coal basins, deposits and individual enterprises. For this reason, the necessary complex of actions for prevention, localization and elimination of negative environmental consequences should be developed before the start of the technical work on the closing of businesses at the stage of pre-project engineering and design.

TABLE I. THE MAIN FACTORS OF NEGATIVE IMPACT OF THE ELIMINATED MINES AND PITS ON THE ENVIRONMENT AND TECHNICAL SOLUTIONS TO PREVENT IT

\begin{tabular}{|c|c|c|c|}
\hline $\begin{array}{c}\text { Factors of } \\
\text { negative im- } \\
\text { pact on the } \\
\text { environment }\end{array}$ & $\begin{array}{l}\text { Elements } \\
\text { of the } \\
\text { envi- } \\
\text { ronment }\end{array}$ & $\begin{array}{l}\text { Types of negative } \\
\text { impact on the } \\
\text { environment }\end{array}$ & $\begin{array}{c}\text { Technical } \\
\text { solutions to } \\
\text { prevent } \\
\text { negative } \\
\text { impacts }\end{array}$ \\
\hline $\begin{array}{l}\text { Termination of } \\
\text { production } \\
\text { activities of } \\
\text { coal enterprises }\end{array}$ & $\begin{array}{c}\text { Natural } \\
\text { landscape }\end{array}$ & $\begin{array}{l}\text { Removing of } \\
\text { industrial sites, } \\
\text { access railway } \\
\text { tracks and stations, } \\
\text { technological } \\
\text { highways, power } \\
\text { lines, pipelines, } \\
\text { communication } \\
\text { lines, buildings } \\
\text { and structures }\end{array}$ & $\begin{array}{l}\text { Dismantling of } \\
\text { unused } \\
\text { buildings and } \\
\text { constructions, } \\
\text { railway tracks, } \\
\text { pipelines, } \\
\text { power lines, } \\
\text { clearing of } \\
\text { industrial sites }\end{array}$ \\
\hline $\begin{array}{l}\text { Flooding of } \\
\text { mine workings } \\
\text { and the } \\
\text { exhausted areas } \\
\text { of eliminated } \\
\text { mines }\end{array}$ & $\begin{array}{l}\text { Undergro } \\
\text { und water } \\
\text { Earth } \\
\text { surface } \\
\text { Atmosphe } \\
\text { ric air }\end{array}$ & $\begin{array}{l}\text { Filtration, flows } \\
\text { and sudden } \\
\text { breakthroughs of } \\
\text { mine waters from } \\
\text { flooded mines to } \\
\text { mining of adjacent } \\
\text { operating mines } \\
\text { Pollution } \\
\text { underground of } \\
\text { drinking water } \\
\text { intake structures }\end{array}$ & $\begin{array}{l}\text { Create a } \\
\text { waterproof } \\
\text { jumper, } \\
\text { plugging } \\
\text { wells, } \\
\text { elimination of } \\
\text { the pillars, } \\
\text { maintaining the } \\
\text { level of } \\
\text { flooding at a } \\
\text { given elevation }\end{array}$ \\
\hline
\end{tabular}




\begin{tabular}{|c|c|c|c|}
\hline $\begin{array}{l}\text { Factors of } \\
\text { negative im- } \\
\text { pact on the } \\
\text { environment }\end{array}$ & $\begin{array}{l}\text { Elements } \\
\text { of the } \\
\text { envi- } \\
\text { ronment }\end{array}$ & $\begin{array}{l}\text { Types of negative } \\
\text { impact on the } \\
\text { environment }\end{array}$ & $\begin{array}{c}\text { Technical } \\
\text { solutions to } \\
\text { prevent } \\
\text { negative } \\
\text { impacts }\end{array}$ \\
\hline & & $\begin{array}{l}\text { and groundwater } \\
\text { waters that can be } \\
\text { used for drinking } \\
\text { water supply } \\
\text { Flows and outlets } \\
\text { in the form of } \\
\text { springs polluted } \\
\text { mine waters to the } \\
\text { surface drains of } \\
\text { rock dumps, their } \\
\text { entry into the sur- } \\
\text { face water bodies } \\
\text { and relief, water } \\
\text { pollution, rivers } \\
\text { and coasts } \\
\text { Deformation of } \\
\text { the earth's surface, } \\
\text { the formation of } \\
\text { depressions, } \\
\text { failures, } \\
\text { displacement of } \\
\text { the sides of the } \\
\text { pits, landslides, } \\
\text { disruption and } \\
\text { destruction of } \\
\text { transmission lines, } \\
\text { industrial } \\
\text { buildings and } \\
\text { structures } \\
\text { Displacement of } \\
\text { mine gases from } \\
\text { flooded mine } \\
\text { workings and the } \\
\text { exhausted areas, } \\
\text { an exit to a surface } \\
\text { and accumulation } \\
\text { of gases in wells, } \\
\text { basements of } \\
\text { buildings and } \\
\text { rooms, the low- } \\
\text { lands }\end{array}$ & $\begin{array}{l}\text { due to pumping } \\
\text { of mine waters, } \\
\text { construction of } \\
\text { drainage at } \\
\text { operating mines } \\
\text { Creation of } \\
\text { anti-filtration } \\
\text { curtains, } \\
\text { barrage systems } \\
\text { Collection and } \\
\text { purification of } \\
\text { flowing to the } \\
\text { surface mine } \\
\text { waters, waste } \\
\text { rock dumps of } \\
\text { mining sites, } \\
\text { pumping of } \\
\text { mine waters in } \\
\text { the deeper } \\
\text { aquifers, } \\
\text { surface water } \\
\text { drainage from } \\
\text { rock dumps } \\
\text { Construction of } \\
\text { exhausted the } \\
\text { areas, the } \\
\text { strengthening of } \\
\text { foundations of } \\
\text { buildings, } \\
\text { filling of gaps } \\
\text { Construction of } \\
\text { drainage } \\
\text { systems for } \\
\text { lowering the } \\
\text { groundwater } \\
\text { level and } \\
\text { drainage } \\
\text { systems for col- } \\
\text { lection, removal } \\
\text { and treatment } \\
\text { of pumped } \\
\text { mine and } \\
\text { drainage waters } \\
\text { Controlled } \\
\text { release of mine } \\
\text { gases through } \\
\text { specially } \\
\text { equipped gas- } \\
\text { drainage pipes, } \\
\text { gas isolation of } \\
\text { the basements } \\
\text { of buildings, the } \\
\text { device of gas- } \\
\text { tight floors, } \\
\text { forced ventilation of } \\
\text { basements }\end{array}$ \\
\hline $\begin{array}{lr}\begin{array}{l}\text { Storage } \\
\text { waste }\end{array} & \text { of } \\
\text { dumps, opte } & \text { open } \\
\text { coal storages, } \\
\text { mud collectors, } \\
\text { industrial reser- } \\
\text { voirs.) }\end{array}$ & $\begin{array}{l}\text { Land re- } \\
\text { sources } \\
\text { Atmos- } \\
\text { pheric air } \\
\text { Water re- } \\
\text { sources }\end{array}$ & $\begin{array}{l}\text { Exemption from } \\
\text { land-use areas, } \\
\text { technogenic forms } \\
\text { of landscape } \\
\text { Emission of dust } \\
\text { and gaseous } \\
\text { harmful } \\
\text { substances, } \\
\text { especially in case } \\
\text { of fire or } \\
\text { spontaneous } \\
\text { combustion } \\
\text { Generation of } \\
\text { polluted drains }\end{array}$ & $\begin{array}{l}\text { Extinguishing } \\
\text { of burning rock } \\
\text { dumps and } \\
\text { centers of } \\
\text { spontaneous } \\
\text { combustion, } \\
\text { implementation } \\
\text { of preventive } \\
\text { measures, } \\
\text { Reclamation of } \\
\text { the occupied } \\
\text { territory } \\
\text { Collection and } \\
\text { treatment of } \\
\text { wastewater }\end{array}$ \\
\hline
\end{tabular}

\begin{tabular}{|l|l|l|l|}
\hline $\begin{array}{c}\text { Factors of } \\
\text { negative im- } \\
\text { pact on the } \\
\text { environment }\end{array}$ & $\begin{array}{c}\text { Elements } \\
\text { of the } \\
\text { envi- } \\
\text { ronment }\end{array}$ & $\begin{array}{l}\text { Types of negative } \\
\text { impact on the } \\
\text { environment }\end{array}$ & $\begin{array}{c}\text { Technical } \\
\text { solutions to } \\
\text { prevent } \\
\text { negative } \\
\text { impacts }\end{array}$ \\
\hline $\begin{array}{l}\text { Disturbed, and } \\
\text { polluted and } \\
\text { degraded lands }\end{array}$ & $\begin{array}{l}\text { Land re- } \\
\text { sources }\end{array}$ & $\begin{array}{l}\text { Unsuitability of } \\
\text { the land for } \\
\text { economic use }\end{array}$ & $\begin{array}{l}\text { Reclamation of } \\
\text { lands and pits } \\
\text { for their } \\
\text { subsequent use }\end{array}$ \\
\hline
\end{tabular}

Flooded mines often border on remaining in the exploitation of nearby mines was eliminated workings with them or having hydraulic connection, which leads to overflows of water in the existing mines and threaten a sudden breakthrough of water. This causes the need to increase the productivity of water pumping in operating mines or construction of drainage systems in eliminated mines in order to maintain a safe level of groundwater. For the solution of problems of protection of groundwater from pollution in case of flooding mines it is necessary, first of all, the performance of the broad hydrogeological investigations, including conducting of monitoring of underground mine waters, the assessment of hydrodynamic and hydrochemical state of groundwater, making hydrodynamic forecasts, the development of special protective measures. It is necessary to provide measures to reduce the inflow of water into the mines and pits, the degree of pollution of mine and groundwater [10].

The elimination of the negative environmental consequences of mine elimination and the neutralization of newly emerging sources of environmental risk require large material costs. To reduce costs, a balanced, scientifically sound approach to solving this very complex and important problem, the creation and effective functioning of an environmental monitoring system, deep elaboration and operational implementation of environmental measures taking into account the actual situation in coal regions is necessary. To save jobs, on the basis of mines it is necessary to create construction and mining and capital departments specializing in the reconstruction of mines. Recultivated area after mine elimination should be free from destroyed buildings and structures suitable for agricultural work. The mouths of shafts and borings should be concreted, in which devices for monitoring the environmental impact of eliminated mine on the environment should be installed.

\section{CONCLUSION}

The further increase in the number of closed mines in the region and the expansion of areas where processes of technogenic changes in the environment are intensively developing make it necessary to carry out the following activities [11]:

advanced assessment of the impact of mine elimination on the environmental condition;

identification of areas of potential flooding of places of storage of liquid and solid waste, geochemical pollution of landscapes (industrial sites, terrains);

development on the basis of advanced forecasts of basin and territorial schemes of groundwater level regime management;

development of a regional forecast of groundwater quality changes in order to justify the composition of 
measures to protect them and improve the environmental sustainability of drinking water supply systems;

development of predictive models of environmental change, preparation of recommendations for decisionmaking on prevention of environmental disasters;

improvement of monitoring systems at local and regional levels, first of all, geological environment (level and hydrogeochemical regime of groundwater, hazardous geological processes, methane migration, etc.);

the creation of regional state administration department for integrated environmental and economic management areas in areas impacted by eliminated mines;

development for the these purposes on the basis of GIStechnologies of permanent models with the formation of functional databases;

utilization of technogenic wastes, which are, on the one hand, a factor of harmful impact on the environment and, on the other hand, an unconventional source of a number of scarce useful components;

to solve problems associated with the effects of the mines elimination, more extensive use of potential of scientific, design and industrial organizations;

ensuring financing of environmental protection measures for studying, preventing and eliminating consequences of mass mines elimination from budgets of different levels.

Thus, the environmental consequences of mines elimination must be calculated in advance at the design stage based on environmental monitoring data. In the newly discovered and prepared for testing deposits working settlements, production facilities should be located taking into account the preservation of natural phytocenoses.

\section{REFERENCES}

[1] S. Kostyuk, N. Bedarev, O. Lyubimov, and A. Shaikhislamov, "The Mine Working's Roof Stress-strain State Research in the Perspective of Development of New Coal Deposits of Kuzbass," E3S Web of Conferences, Vol. 21, 2017.

[2] P. Grechishkin, E. Razumov, O. Petrova, A. Kozlov, and E. Aushev, "Rock Deformation Behavior Near Excavations Under the Influence of High Tectonic Stress in Coal Seam V-12, "Severnaya" Mine, JSC "Urgalugol," E3S Web of Conferences, Vol. 21, 2017.

[3] M. Cehlár, J. Engel, J. Mihok, and R. Rybár, "Edičné stredisko," AMS F-BERG, Košice, 2006.

[4] P. Grechishkin, E. Razumov, O. Petrova, A. Kozlov, and E. Aushev, "Rock Deformation Behavior Near Excavations Under the Influence of High Tectonic Stress in Coal Seam V-12, "Severnaya" Mine, JSC "Urgalugol," E3S Web of Conferences, Vol. 21, 2017.

[5] M. Cehlár, J. Janočko, Z. Šimková, and T. Pavlik, "Assessment process of concept for mining and its impact on the region," E3S Web of Conferences, Vol. 15, 2017.

[6] S. Prokopenko, I. Kurzina, and Yu. Lesin, "Prospects for improvement of mining mashines` cutting risks," IOP Conference Series: Materials Science and Engineering, 2016.

[7] Zh. Haifeng, "Study on mine strata pressure behavior law of irregular fully-mechanized top coal caving mining face in seam shallow depth," Coal Science and Technology, 2015.

[8] N. Pirieva, and I. Ermakova, "The Extent of Destruction Zones Within Protective Pillars in Jsc "Suek-Kuzbass" Underground Mines," E3S Web of Conferences, Vol. 21, 2017.

[9] K. Fuławka, P. Mertuszka, and W. Pytel, "Monitoring of the stability of underground workings in Polish copper mines conditions, “ E3S Web of Conferences, Vol. 29, 2018

[10] M. Cehlár, R. Rybár, J. Pinka, L. Haxhiu, and M. Beer, "Analysis of Suitability for Development of New Mining Field in Northern Part of Kosovo Lignite Basin-Sibovc," Archives of Mining Sciences 58 (2), 2013.

[11] L. Mametev, A. Khoreshok, A. Tsekhin, and A. Borisov, "Disk rock cutting tool for the implementation of resourse-saving technologies of mining of solid minerals," E3S Web of Conferences, The Second International Innovative Mining Symposium, 2017.

[12] M. Cehlár, and ড̌. Kuzevič, "Environmental Insurance for Brownfields Redevelopment Activities and Feasibility Study as an basic part of Complex solution," Acta Montanistica Slovaca, 2064 (9), 